Tạp chí Các Khoa học về Trái Đất, 38 (1), 22-37

\begin{tabular}{c} 
Viện Hàn lâm Khoa học và Công nghệ Việt Nam \\
Tạp chí Các Khoa học về Trái Đất \\
(VAST) \\
Website: http://www.vjs.ac.vn/index.php/jse \\
\hline
\end{tabular}

\title{
Đặc điểm dập vỡ kiến tạo vùng Nam Tây Nguyên
}

\author{
Lê Triều Việt*, Văn Đức Tùng, Vũ Cao Chí, Nguyễn Thị Thanh Hương, Nguyễn Văn Luân, Đào Hải \\ Nam, Bùi Văn Quỳnh
}

Viện Địa chất, Viện Hàn lâm Khoa học và Công nghệ Việt Nam

Chấp nhận đăng: 15 - 3 - 2016

ABSTRACT

Characteristics of fracture zones in Southern Tay Nguyen

Interpretation of remote sensing images, analysis topographic maps, DEM maps, combined with field geological,geomorphological, tectonophysical materials and published document, the authors have established a (prognostic) scheme of crustal tectonic fracture zones in southern Tay Nguyen. In this scheme, the tectonic fractures were developed and distributed complexly in both scale and direction. The distributive tectonic fractures may be divided into NW and SE parts. The NW part is characterized by tectonic fractures of NE- SW, NW- SE, sublongitudinal and sublatitudinal directions, although the NE-SW orientation is also developed. Meanwhile, in the SE most of the tectonic fractures are NE-SW direction, whereas NW- SE, sublongitudinal and sublatitudinal fractures are rare. Statistical data show that there are more than 140 tectonic fracture strips with greater than $10 \mathrm{~km}$ in length existed in the study area. The intersection and concentration of the fracture zonesform some junction points that have high prospects for groundwater and good sites for water recharge in some regions of Southern Highlands.

Keywords: Fracture zones, lineament, the southern of Tay Nguyen.

C2016 Vietnam Academy of Science and Technology

\section{Mở đầu}

Dập vỡ kiến tạo là sản phẩm của quá trình hoạt động nội sinh thể hiện ở sự gãy vỡ cà nát các thành tạo địa chất. Dập vỡ kiến tạo được hình thành do sự di chuyển của các khối địa chất, do hoạt động đứt gãy, hoạt động động đất, hoạt động phun trào và xâm nhập hay đơn giản chỉ là do sự biến dạng gẫy gập của một tầng đất đá nào đó dưới tác động của các yếu tố nội sinh. Tuy nhiên, phần lớn các dạng dập vỡ kiến tạo được hình thành trong các trường hợp hoạt động kiến tạo phá hủy (biến dạng giòn- Britle deformation) và được thể hiện là các đới gãy vỡ, các đới trượt cắt, các đới dăm kết kiến tạo và các đới khe nứt tăng cao. Do đó, dập vỡ

*Tác giả liên hệ, Email: letrieuviet@yahoo.com.vn kiến tạo là một trong những yếu tố quan trọng để đánh giá mức độ hoạt động kiến tạo của khu vực nào đó và là luận cứ đáng tin cậy cho việc luận giải hoạt động Tân kiến tạo và kiến tạo hiện đại.

Việc nghiên cứu dập vỡ kiến tạo vỏ Trái đất được thực hiện ở nhiều nơi trên thế giới trong thi công các công trình xây dựng, trong nghiên cứu hoạt động đứt gãy phục vụ đánh giá tai biến địa chất, trong khai thác mỏ và tìm kiếm khoáng sản hay nước ngầm,... Đặc biệt, ngày nay, việc nghiên cứu đối tượng này đang được mở rộng đến cả những vùng khô hạn và bán khô hạn nơi khan hiếm nước mặt (nước mưa, nước sông, hồ) nhằm phát hiện các vị trí tồn tại cũng như tiềm năng nước ngầm trong chúng hay sử dụng chúng vào việc bổ cập nước nhân tạo. 


\section{L.T. Việt và nnk/Tạp chí Các Khoa học về Trái Đất, Tập 38 (2016)}

Vùng Nam Tây Nguyên nước ta, nhiều năm mùa khô kéo dài (đến 5-6 tháng) gây hạn hán và thiếu nước trầm trọng, làm ảnh hưởng lớn đến cuộc sống dân sinh cũng như trồng trọt ở một số nơi. Các giải pháp nhằm duy trì ổn định mực nước ngầm cũng như tăng lượng nước khai thác phục vụ chống hạn và ổn định cuộc sống dân sinh đã được các cấp các ngành rốt ráo thực hiện. Nhưng sự bức xúc vì thiếu nước mỗi năm càng gia tăng. Để góp phần vào việc khắc phục sự bức xúc đó, các nhà khoa học nước ta đã và đang tìm đến giải pháp đưa nước một cách nhân tạo vào lòng đất (bổ sung nước nhân tạo) (Đoàn Văn Cánh và nnk, 2010) nhằm duy trì sự ổn định mực nước ngầm phục vụ khai thác bền vững, đặc biệt mỗi khi mùa khô kéo dài. Mặc dù hướng nghiên cứu này đã có nhiều kinh nghiệm thực tiễn ở nước ngoài, tuy nhiên ở nước ta hướng nghiên cứu này vẫn còn là điều mới mẻ.

Để thực hiện giải pháp bổ sung nước nhân tạo vào lòng đất có hiệu quả cao thì việc nghiên cứu phát hiện các đới dập vỡ kiến tạo có quy mô lớn trong các thành tạo địa chất là việc đầu tiên cần tiến hành. Đây cũng là nội dung quan trọng đang được chúng tôi tiến hành nghiên cứu trong quá trình thực hiện đề tài nghiên cứu khoa học, mã số TN3/T24 cho vùng Tây Nguyên. Trong khuôn khổ bài báo này, chúng tôi giới thiệu một số kết quả nghiên cứu ban đầu về dập vỡ kiến tạo của vùng Nam Tây Nguyên.

Vùng nghiên cứu bao gồm địa bàn của tỉnh Lâm Đồng, tỉnh Đắk Nông và phần nam của tỉnh Đắk Lắk.

\section{Cơ sở phương pháp luận và các phương pháp nghiên cứu}

Như trên đã đề cập, dập vỡ kiến tạo là sản phẩm của hoạt động kiến tạo mà chủ yếu là do hoạt động đứt gãy. Dập vỡ kiến tạo có thể tồn tại với nhiều quy mô, kích thước khác nhau trên một diện tích nhất định, nhưng ở đây chúng tôi chỉ đề cập đến dập vỡ kiến tạo tập trung theo một phương kéo dài nào đó tức là có tính chất tuyến tính tựa như các lineament kiến tạo để việc chọn lựa các phương pháp nghiên cứu phù hợp hơn. Vì vậy, để nghiên cứu phát hiện ra các đới dập vỡ các phương pháp nghiên cứu đứt gãy được sử dụng triệt để.

Phương pháp nghiên cứu đầu tiên cần áp dụng cho vùng rộng lớn như Tây Nguyên, nơi địa hình phân cắt phức tạp là phương pháp giải đoán ảnh viễn thám. Đây là phương pháp mang lại hiệu quả nhanh có tính bao quát cao. Trên các tấm ảnh vũ trụ và ảnh máy bay các đới dập vỡ kiến tạo thường thể hiện là các cấu trúc tuyến tính - các photolineament được tạo bởi sự khác biệt về tôn ảnh, màu sắc, hoa văn, kiến trúc và bóng đổ của địa hình.

Ngoài ra, trên ảnh có thể phát hiện các đới dập vỡ thông qua sự tồn tại các dải ao hồ, các dải địa hình thẳng tuyến nơi phát triển thực vật ưa ẩm, một chỉ thị tồn tại các đới dập vỡ gần bề mặt chứa nước ngầm. Đối với vùng nghiên cứu nơi có lớp phủ basalt trẻ phát triển rộng rãi như ở Tây Nguyên thì phương pháp nghiên cứu này là rất cần thiết, để theo dõi xu thế phát triển các đới dập vỡ từ vùng lộ đá cổ tiếp tục dưới lớp phủ basalt. Kết quả giải đoán các tấm ảnh Lansat với độ phân giải cao $(30 \mathrm{~m})$ cho phép thành lập nên sơ đồ photolineament vùng nghiên cứu (hình 1$)$. Uu việt của phương pháp này là tính bao quát cao, không phức tạp. Tuy nhiên, kết quả giải đoán ảnh viễn thám thường cho ta đa nghiệm, cho ta cả một tổ hợp các photolineament không phải là dập vỡ kiến tạo theo dạng tuyến, như: đường giao thông, đường ống và kênh mương dẫn nước, các đoạn đường đỉnh, các vách dốc kéo dài,... Ở vùng núi nơi địa hình phân dị mạnh thì trên ảnh dễ nhận ra các dải dập vỡ. Còn ở vùng địa hình tương đối bằng phẳng, bình địa hay nhấp nhô như địa hình đá phun trào basalt thì việc phát hiện ra các đới dập vỡ không phải dễ dàng. Theo kinh nghiệm (Cẩm nang công nghệ Địa chất, 2010) thì $90 \%$ photolineament giải đoán ở địa hình vùng núi có thể trùng đứt gãy kiến tạo. Còn đối với vùng phủ basalt gần tương tự như vùng đồng bằng thì chỉ có khoảng $10 \%$ photolineament trùng với đứt gãy kiến tạo hay dập vỡ kiến tạo mà thôi. Vì vậy, phải cần đến các giải đoán, phân tích tiếp cận khác đề kiểm chứng, loại bỏ những đối tượng này. Đó là phân tích bản đồ địa hình, phân tích ảnh DEM,... 
Tạp chí Các Khoa học về Trái Đất, 38 (1), 22-37

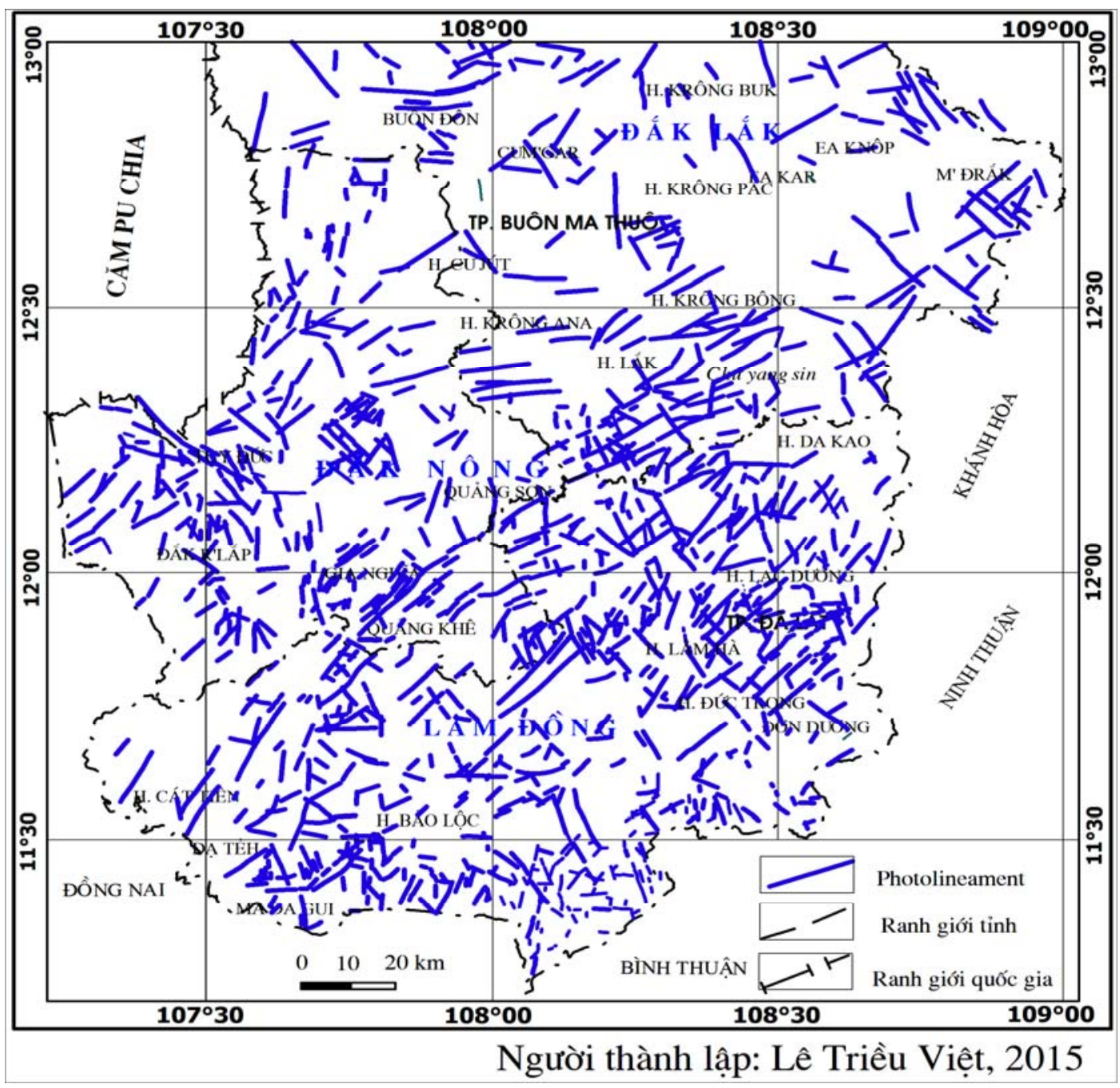

Hình 1. Sơ đồ photolineament vùng Nam Tây Nguyên (thu từ tỷ lệ 1:250.000)

Với việc phân tích bản đồ địa hình cho phép nhận dạng các đới dập vỡ qua sự thẳng tuyến của các sông, suối hay đoạn gấp khúc đột ngột của chúng. Ngoài ra, sự bài trí đặc biệt của mạng lưới thủy văn: dạng song song hay ô mạng cũng cho phép suy luận về sự tồn tại dập vỡ ở dưới sâu. Kết quả phân tích bản đồ địa hình từ tỷ lệ khái quát (tỷ lệ $1: 250.000$ ) đến tỷ lệ chi tiết (chủ yếu là $1: 50.000$ và $1: 25.000$ đôi nơi đến tỷ lệ $1: 10.000$ ) của vùng nghiên cứu cho phép thành lập nên sơ đồ các yếu tố dạng tuyến và có thể đặt tên là sơ đồ lineament theo bản đồ địa hình khu vực nghiên cứu (hình 2).
Sau khi có được kết quả phân tích này ta chồng lên kết quả giải đoán ảnh viễn thám cùng tỷ lệ để đối chiếu xem xét lại các đối tượng-các photolineament. Các photolineament "giả" như đã nêu ở trên sẽ được loại bỏ. Ưu điểm của phương pháp này là ngoài việc khẳng định sự tồn tại dập vỡ kiến tạo, nó cho phép định vị chính xác vị trí các dập vỡ, đôi khi cả kích thước sát thực của dập vỡ.

Tiếp theo, việc khẳng định sự tồn tại các photolineament còn được kiểm chứng bằng các lineament vạch theo mô hình số độ cao (DEM) (hình 3). 
L.T. Việt và nnk/Tạp chí Các Khoa học về Trái Đất, Tập 38 (2016)

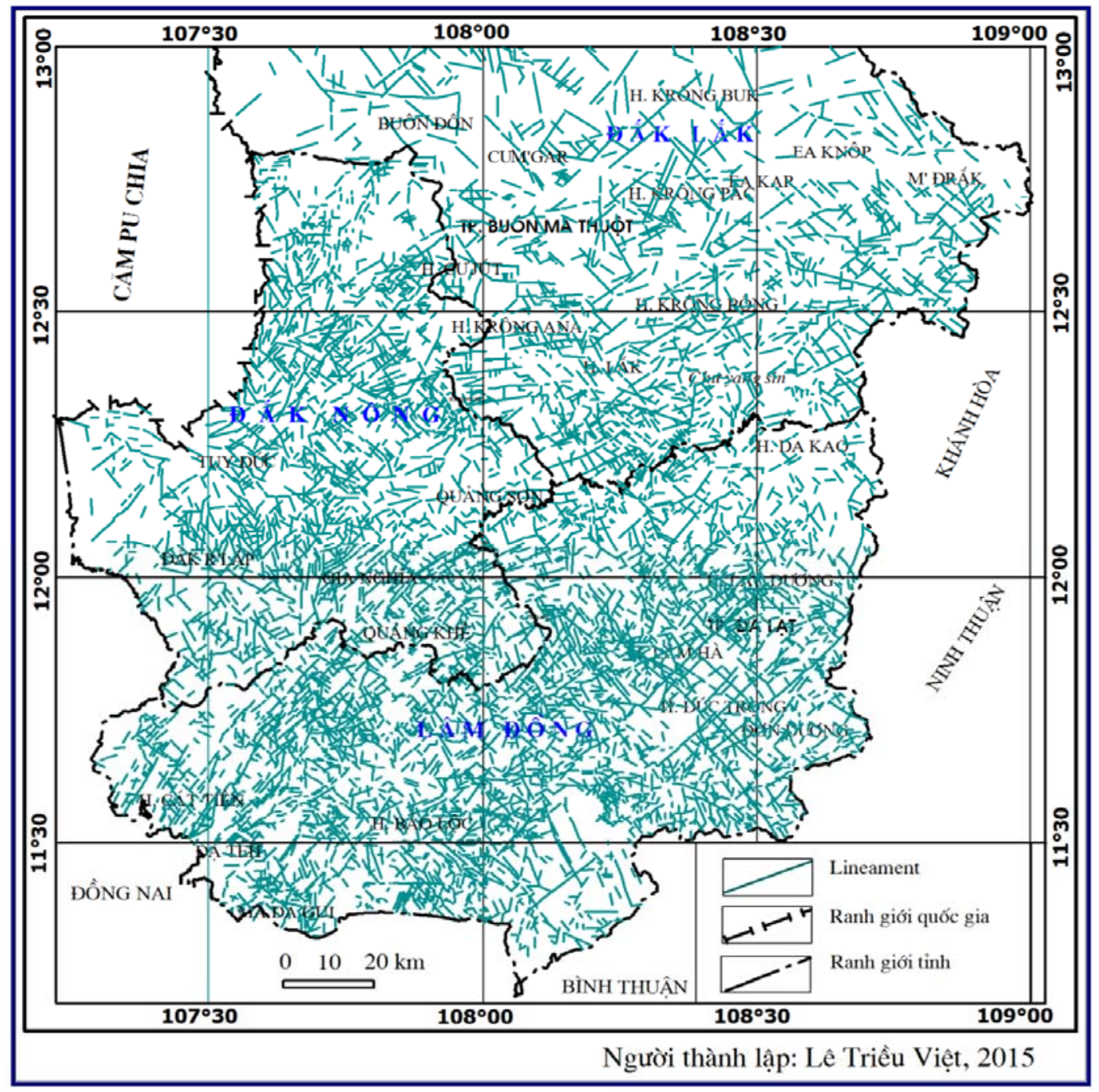

Hình 2. Sơ đồ lineament vùng Nam Tây Nguyên theo phân tích bản đồ địa hình nhiều tỷ lệ (thu từ tỷ lệ 1:250.000) 
Tạp chí Các Khoa học về Trái Đất, 38 (1), 22-37

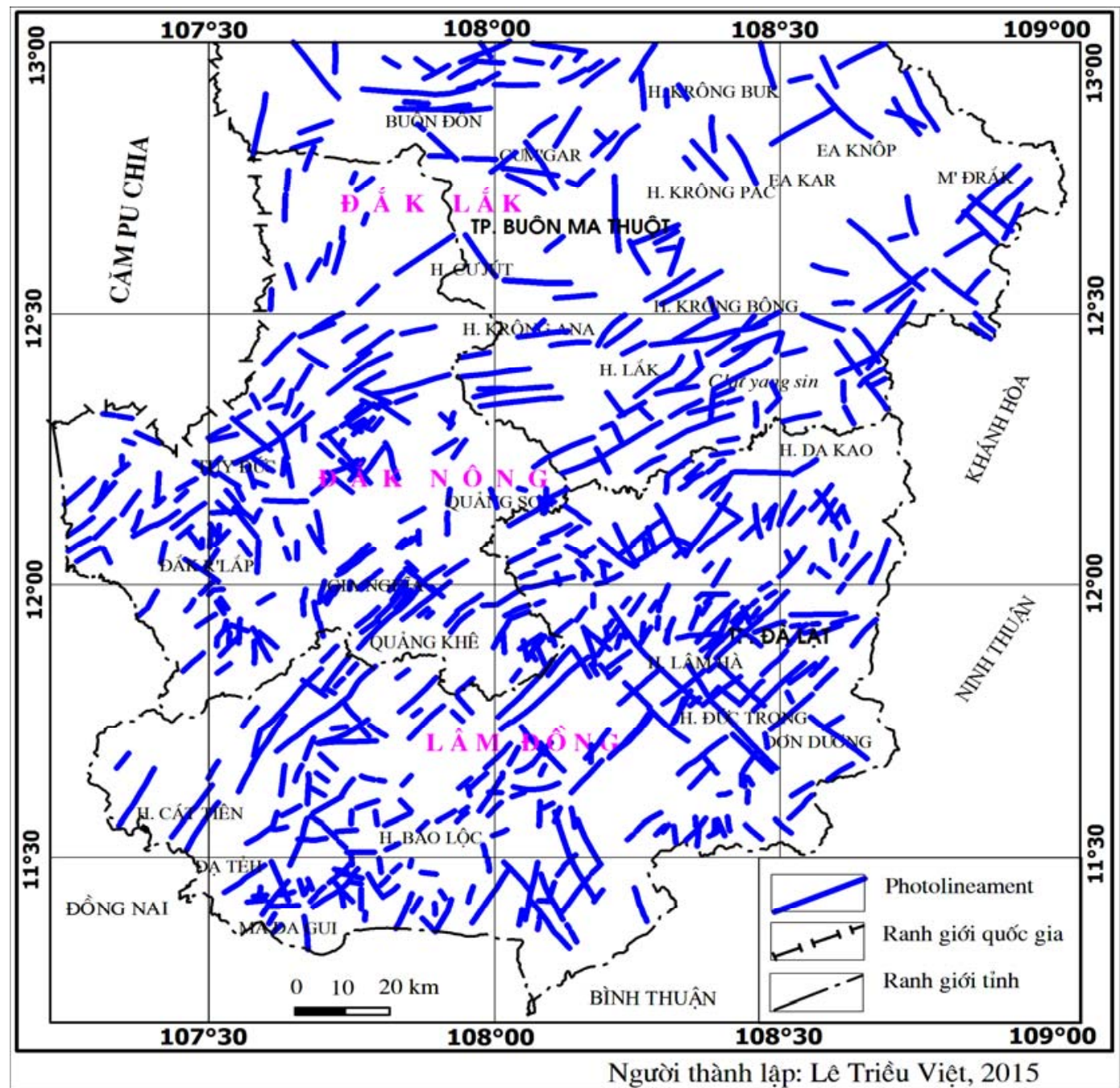

Hình 3. Sơ đồ lineament theo bản đồ DEM vùng Nam Tây Nguyên (thu từ tỷ lệ 1:250.000)

Cuối cùng, từ các số liệu thu được đem phân tích đối sánh với các đứt gãy thể hiện trên loạt bản đồ địa chất vùng Tây Nguyên, tỷ lệ 1:200.000 (Bản đồ địa chất và khoáng sản tỷ lệ 1: 200.000 gồm các tờ: Bản Đôn, Bến Khế, Buôn Ma Thuật, Buprang, B'lao, Đà Lạt- Cam Ranh, Giá Ray, Phan Thiết), các tư liệu từ các công trình nghiên cứu trước đây (Phạm Văn Hùng, Nguyễn Trọng Yêm 1996, 1998; Phạm Văn Hùng, 2000; 2002; Trần Văn Thắng, Văn Đức Tùng, 2004; Trần Văn Thắng, Văn Đức Tùng, Nguyễn Thị Thanh Hương, 2006; và các số liệu khảo sát thực địa (hình 4), chúng tôi thành lập nên sơ đồ dập vỡ kiến tạo vùng Nam Tây Nguyên (hình 5). 
L.T. Việt và nnk/Tạp chí Các Khoa học về Trái Đất, Tập 38 (2016)

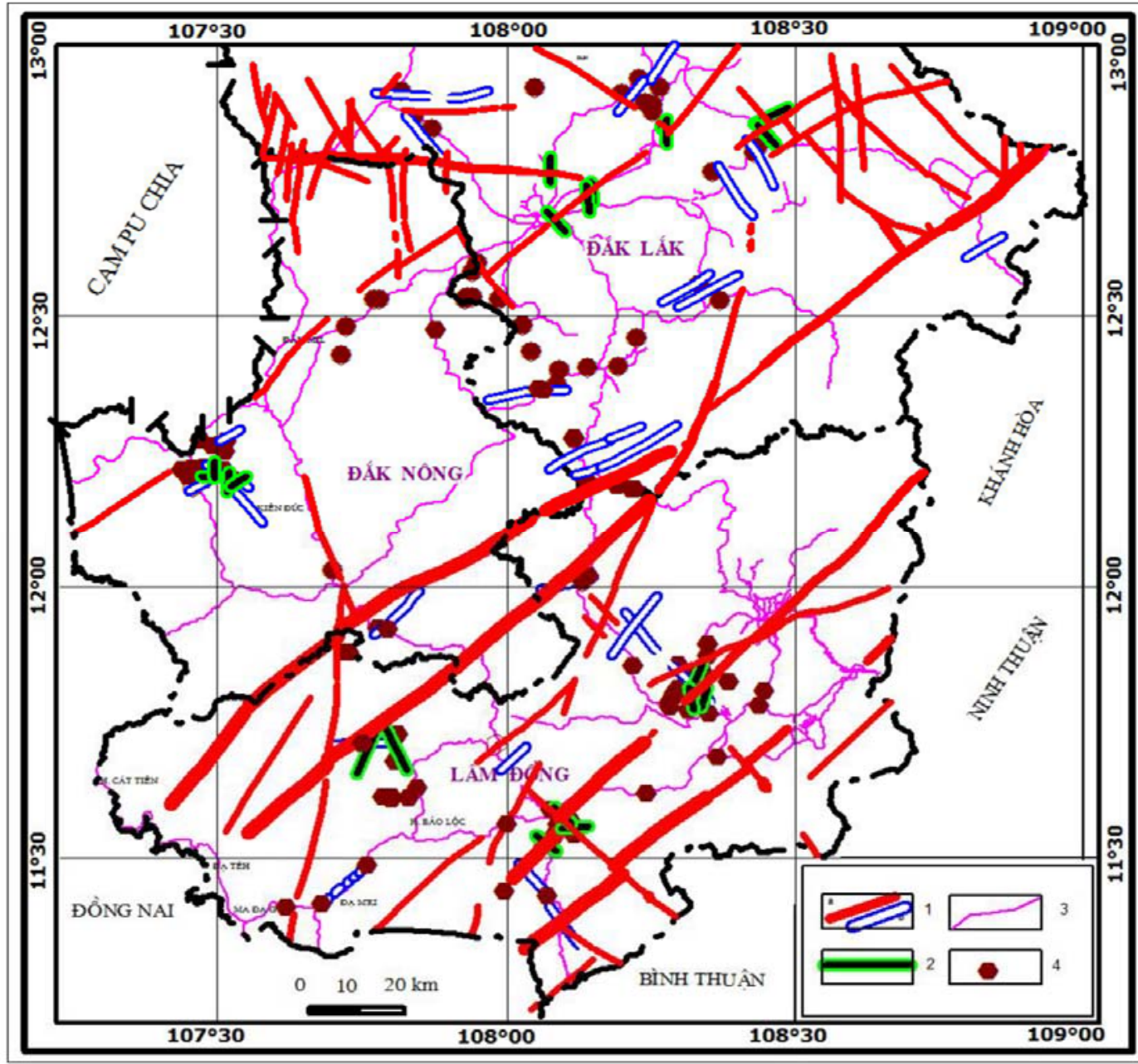

Hình 4. Sơ đồ khảo sát vùng Nam Tây Nguyên

Chú giải: 1a- Đứt gãy theo tài liệu địa chất; 1b- Các dải dập vỡ được kiểm chứng khảo sát thực địa; 2- Các tuyến đo ĐVL xác định DVKT; 3- Đường giao thông; 4- Vị trí khảo sát và đo khe nứt kiến tạo 
Tạp chí Các Khoa học về Trái Đất, 38 (1), 22-37

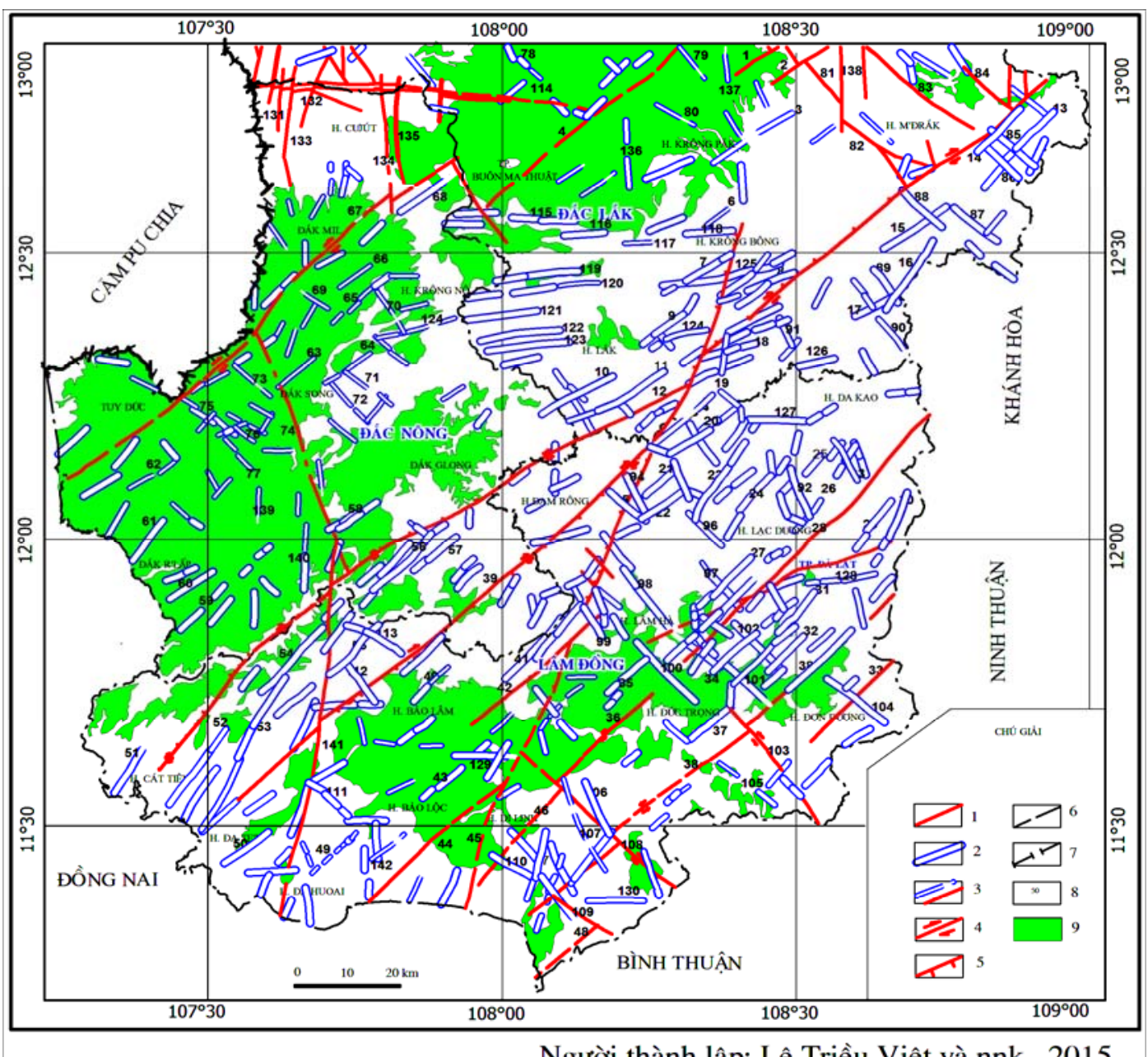

Người thành lập: Lê Triều Việt và nnk., 2015

Hình 5. Sơ đồ phân bố các dải dập vỡ kiến tạo chính vùng Nam Tây Nguyên (thu từ tỷ lệ 1:250.000)

Chú giải: 1. Các dải dập vỡ kiến tạo theo tài liệu bản đồ địa chất; 2. Các dải dập vỡ kiến tạo theo tài liệu: phân tích bản đồ địa hình, ảnh viễn thám và địa mạo; 3. Các dải dập vỡ kiến tạo kém xác định; 4. Phần $\mathrm{d}$ ải dập vỡ kiến tạo trùng đứt gãy trượt bằng; 5 . Phần dải dập vỡ kiến tạo trùng đứt gãy thuận và hướng cắm; 6 . Ranh giới tỉnh; 7. Ranh giới quốc gia; 8 . Số hiệu dải dập vỡ; 9 . Vùng phát triển phun trào basalt Kainozoi muộn

\section{Kết quả nghiên cứu}

\subsection{Nhận xét chung}

Từ các tài liệu trên cho thấy tính dập vỡ kiến tạo của khu vực Nam Tây Nguyên thể hiện khá rõ trên ảnh cũng như trên địa hình tại những nơi địa hình phân dị mạnh (vùng núi hay đồi cao). Ở đó các đới dập vỡ thể hiện rất sắc nét và thường có quy mô lớn (chiều dài đến hàng chục kilomet) (hình 6).
Còn ở những nơi là các cao nguyên basalt hay bình nguyên, nơi địa hình phân dị yếu, lớp vỏ phong hóa dày (cao nguyên Buôn Ma Thuột, cao nguyên Đắk Nông, cao nguyên Di Linh) thì sự dập vỡ kiến tạo có biểu hiện mờ nhạt hoặc là thưa thớt. Quy mô, kích thước (chiều rộng cũng như chiều dài) của chúng thường hẹp, ngắn so với ở vùng núi (hình 7). 
L.T. Việt và nnk/Tạp chí Các Khoa học về Trái Đất, Tập 38 (2016)

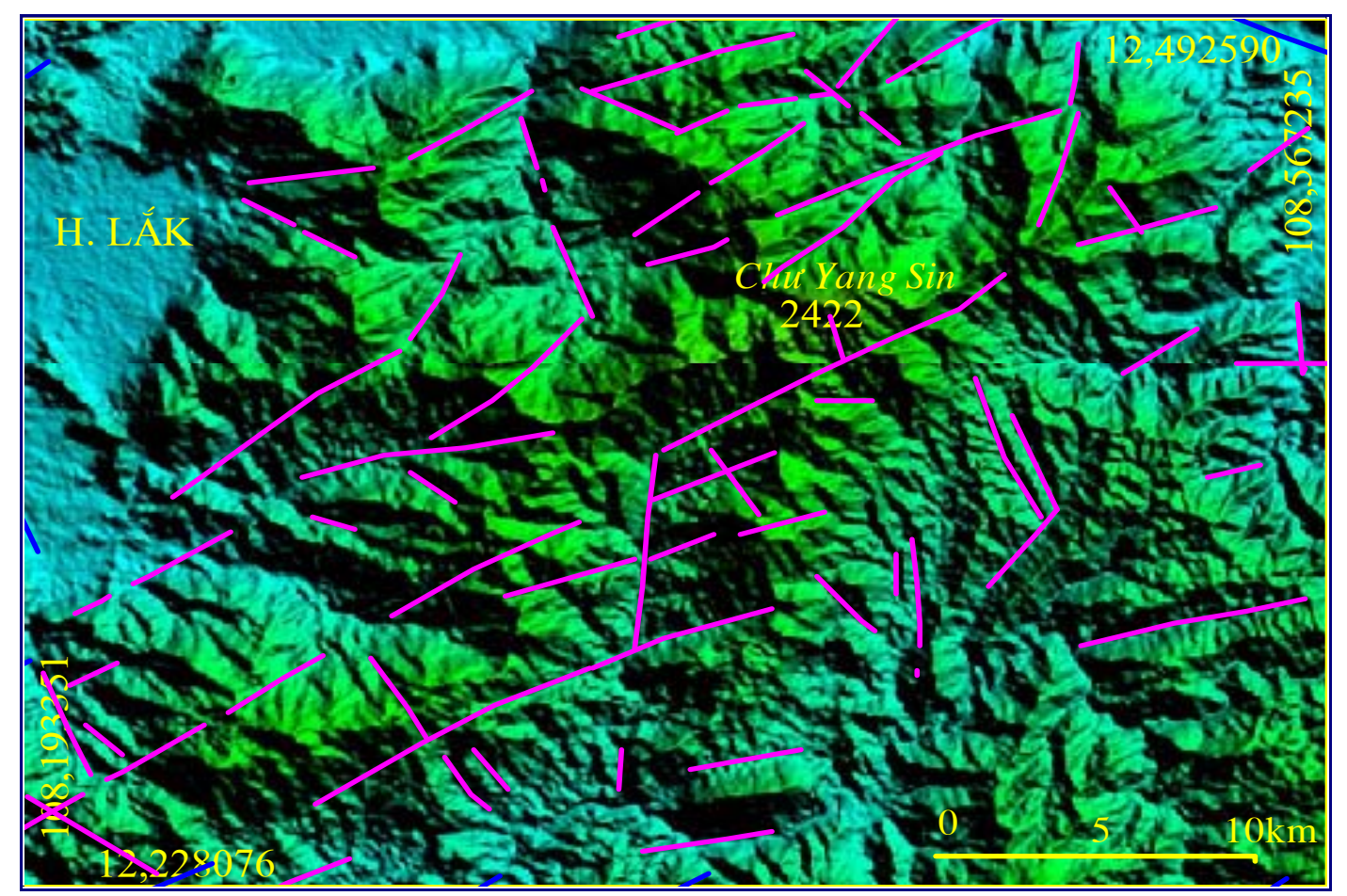

Hình 6. Dập vỡ kiến tạo phương ĐB-TN thể hiện sắc nét ở vùng núi Chư Yang Sin thuộc h. Lắk, tỉnh Đắk Lắk

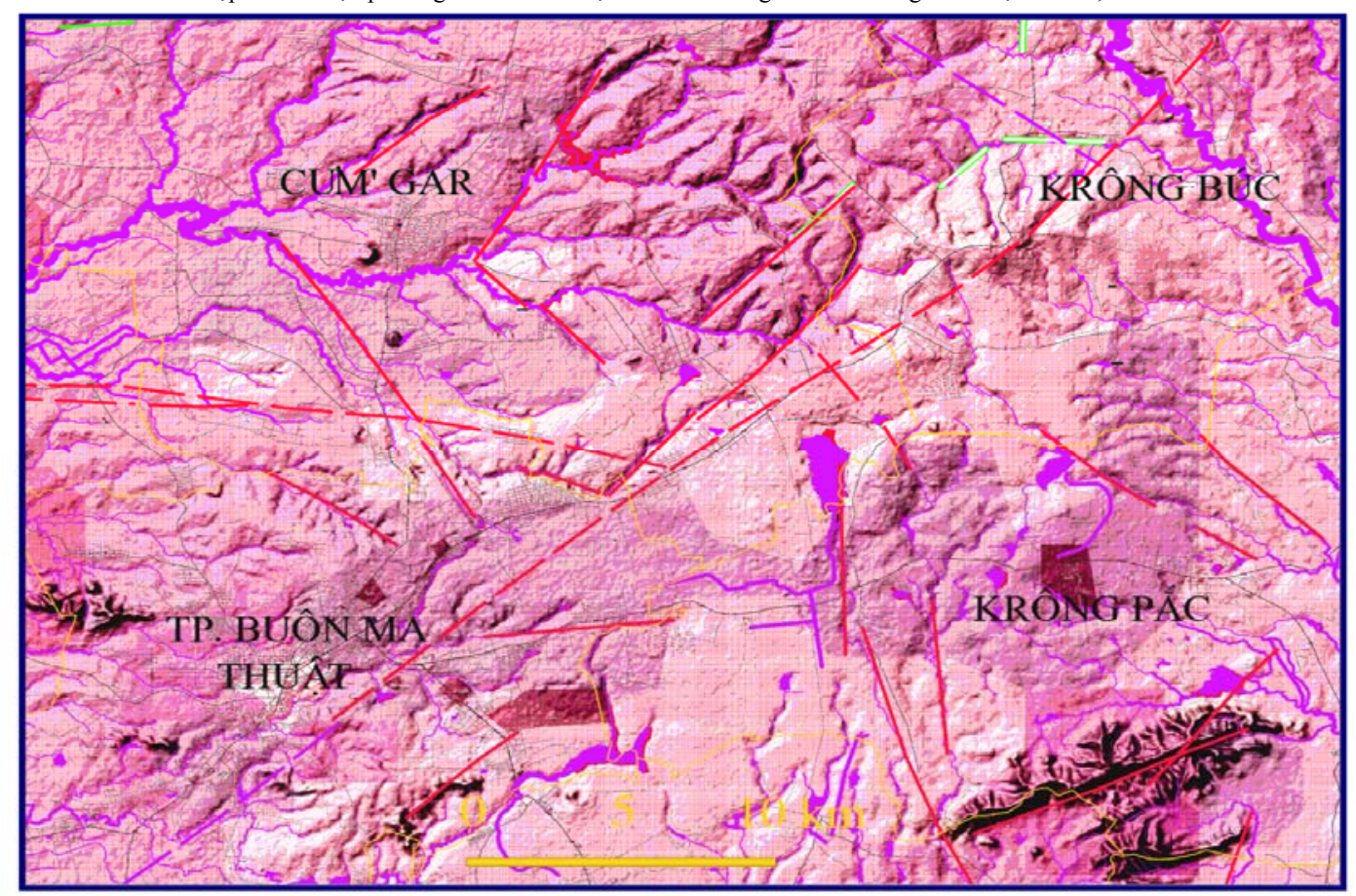

Hình 7. Sự thể hiện thưa thớt của DVKT trên cao nguyên basalt Buôn Ma Thuột 
Tạp chí Các Khoa học về Trái Đất, 38 (1), 22-37

Sự phân bố dập vỡ kiến tạo của vùng Nam Tây Nguyên thể hiện là rất phức tạp và đặc tính dập vỡ rất khác biệt giữa các vùng miền (hình 5 ).

Trên sơ đồ hình 5 , theo sự hiện diện dập vỡ có thể chia vùng nghiên cứu thành 2 phần: $\mathrm{TB}$ và $\mathrm{N}$ với ranh giới giữa hai phần chạy qua vị trí tiếp giáp của 3 tỉnh: Đắk Lắk, Lâm Đồng và Đắk Nông.

Ở phần TB tính dập vỡ phát triển khá đều theo đủ các phương chính: TB- ĐN, ĐB- TN, kinh tuyến- á kinh tuyến, vĩ tuyến và á vĩ tuyến. Trong khi đó ở phần ĐN dập vỡ phương ĐB- $\mathrm{TN}$ và $\mathrm{TB}-$ ĐN phát triển áp đảo. Còn dập vỡ phương á kinh tuyến và á vĩ tuyến hầu như không phát triển.

Dập vỡ kiến tạo có xu thế tạo thành dải với quy mô lớn và thường tập trung ở ranh giới giữa các tỉnh (Đắk Lắk với Khánh Hòa, Đắk Lắk với Lâm
Đồng, Đắk Nông với Lâm Đồng), nơi có địa hình núi cao, phân dị mạnh. Còn ở các vùng đồi (cao nguyên Buôn Ma Thuột, Di Linh, Đắk Nông) là những nơi phát triển phun trào basalt trẻ thì sự phát triển dập vỡ kiến tạo thể hiện yếu hơn, cả về quy mô cũng như mật độ phân bố.

Ở phần $\mathrm{TB}$ vùng nghiên cứu, nghiên cứu chi tiết cho thấy dập vỡ kiến tạo được thể hiện qua sự tồn tại các khe nứt mặt trượt trong mọi thành tạo địa chất. Chúng tồn tại trong các đá biến chất tuổi Proterozoi (hệ tầng Khâm Đức) (hình 8), đá magma tuổi Paleozoi - Mesozoi (phức hệ Bến Giằng - Quế Sơn, phức hệ Vân Canh, phức hệ Định Quán), trong các đá trầm tích tuổi PaleozoiMeszoi (hệ tầng Đắk Lin, Chư Prông, La Ngà, Ea Súp, Đắk Rium (hình 9,10$)$ và trong cả các thành tạo trầm tích hay trong đá basalt tuổi Kainozoi muộn (hệ tầng Túc Trưng) (hình 11).

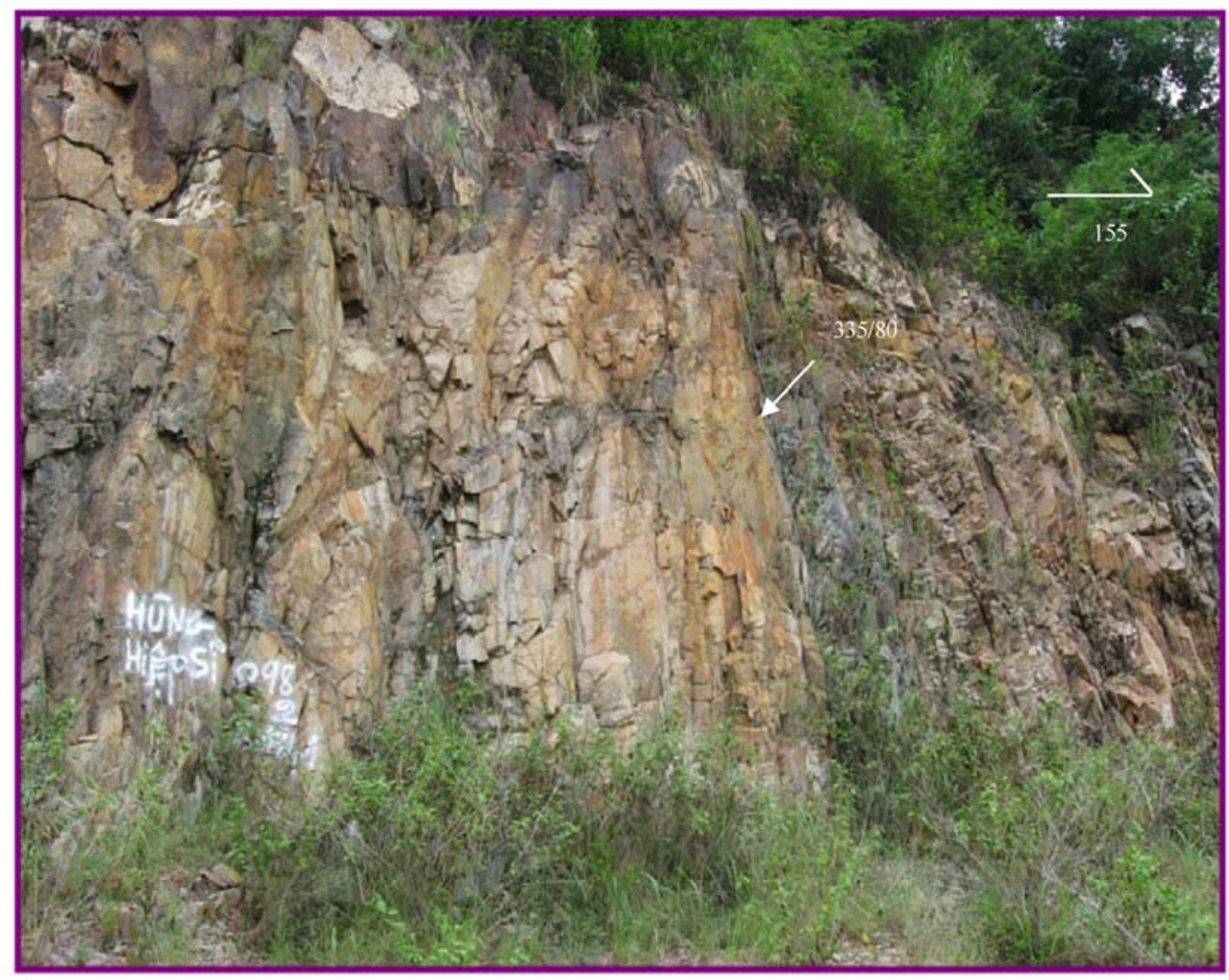

Hình 8. Khe nứt, mặt trượt đổ về TB trong đá biến chất tuổi Proterozoi ht. Khâm Đức, thể hiện sự tồn tại dập vỡ kiến tạo phương ĐB-TN tại xã Ea Trang, h. M’Đrắk, tỉnh Đắk Lắk (ảnh Lê Triều Việt, 2014) 
L.T. Việt và nnk/Tạp chí Các Khoa học về Trái Đất, Tập 38 (2016)

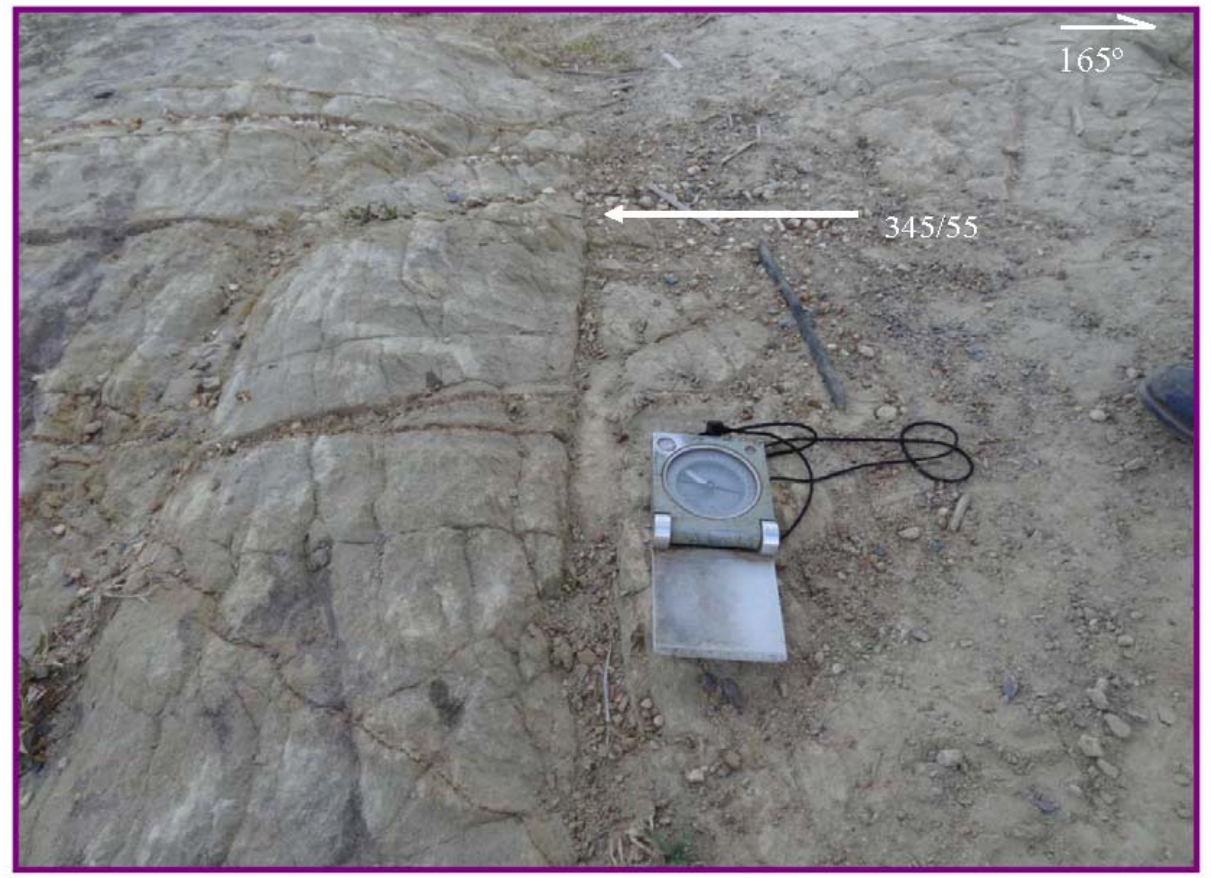

Hình 9. Khe nứt, mặt trượt đổ về $\mathrm{B}-\mathrm{TB}\left(345^{\circ} / 55^{\circ}\right)$ trong trầm tích ht. La Ngà, thể hiện dập vỡ kiến tạo tồn tại theo phương á vĩ tuyến, ở hồ Buôn Triết, h. Lắk, t. Đắk Lắk. Ảnh Lê Triều Việt, 2014

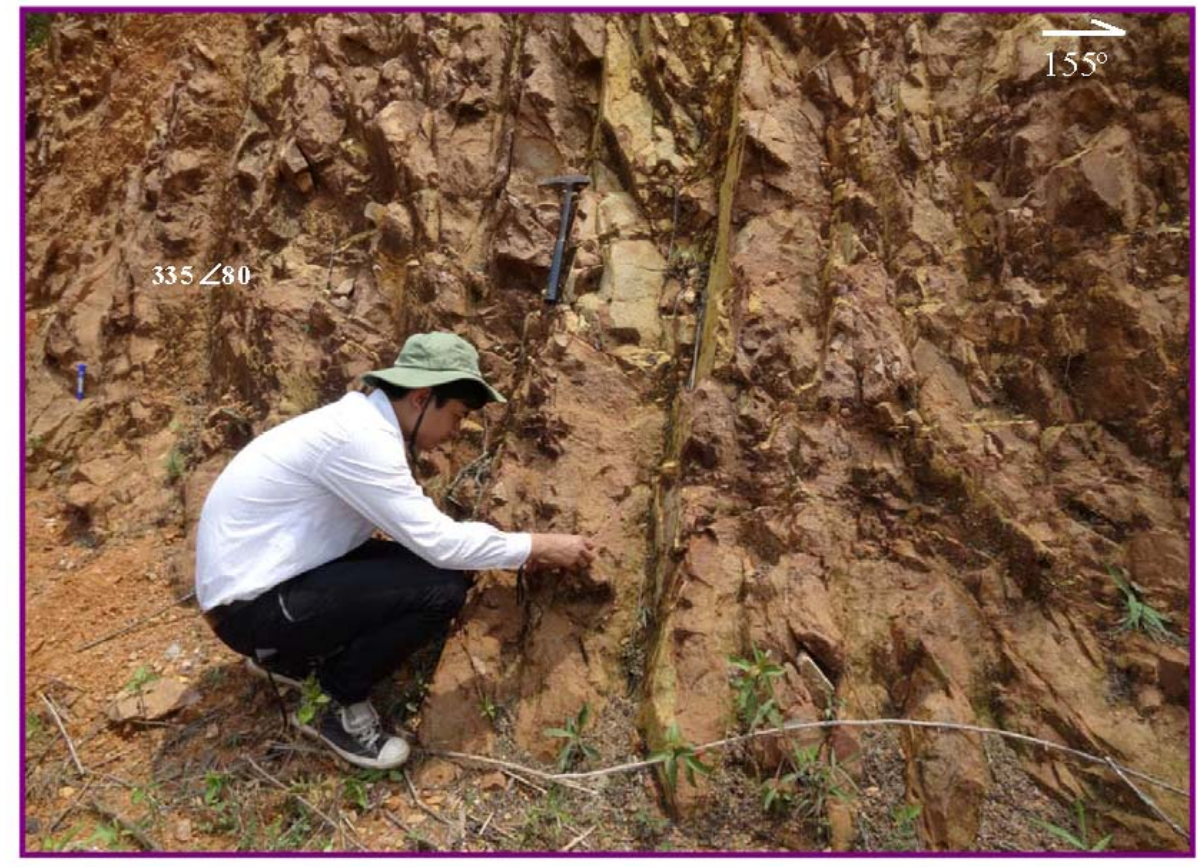

Hình 10. Dập vỡ kiến tạo phương $\mathrm{TB}$ - ĐN được biểu hiện qua các khe nứt trong hệ tầng Đắk Rium tuổi Jura muộn ở TN thị trấn Nam Ban, huyện Lâm Hà, tỉnh Lâm Đồng (ảnh: Lê Triều Việt, 2014) 
Tạp chí Các Khoa học về Trái Đất, 38 (1), 22-37

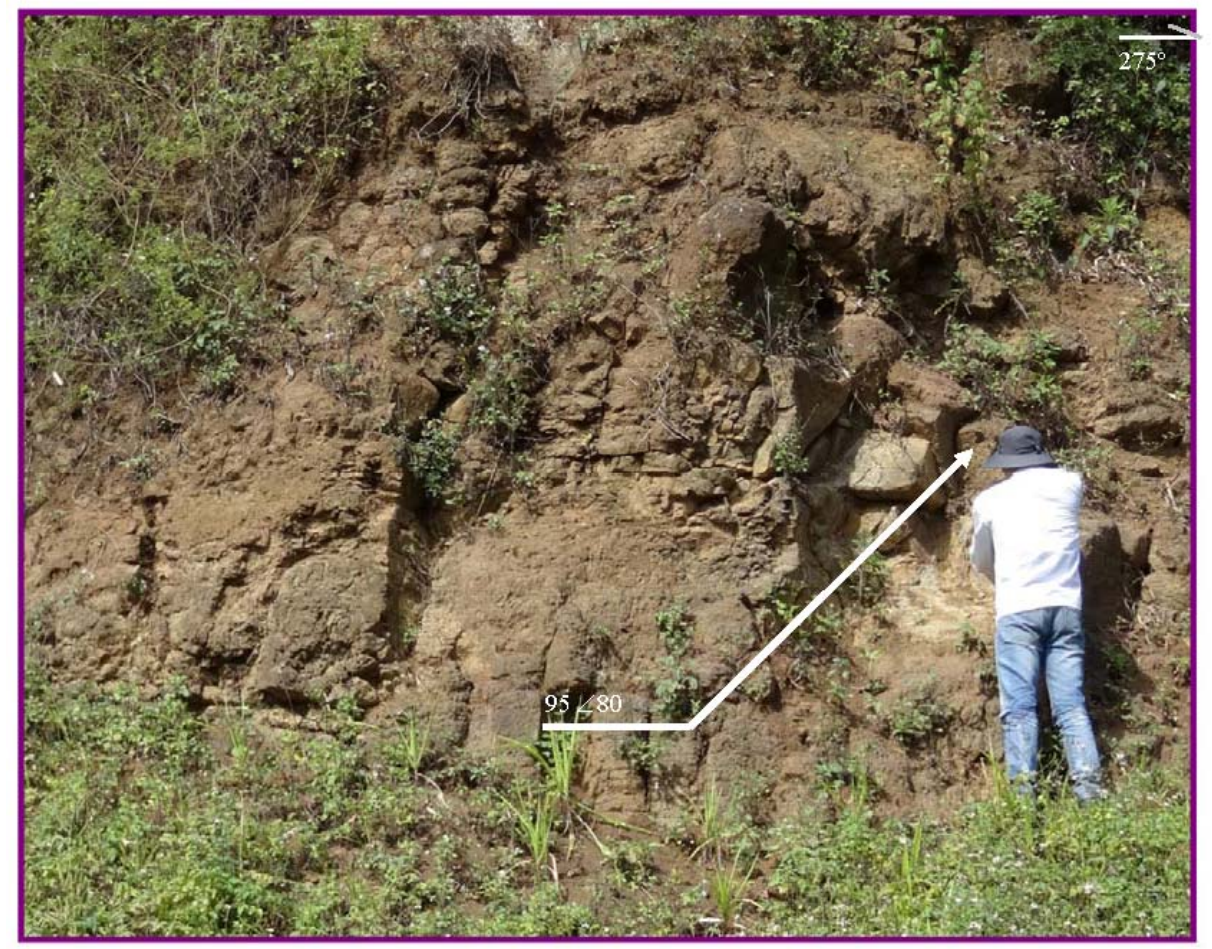

Hình 11. Dập vỡ kiến tạo phương á kinh tuyến được ghi nhận qua các khe nứt cùng phương trong đá phun trào basalt (ht. Túc Trưng) ở phía tây tt. Tam Giang, huyện Krông Búk, tỉnh Đắk Lắk. Ảnh Lê Triều Việt, 2014

Sự phân bố cũng như quy mô phát triển dập vỡ kiến tạo (DVKT) ở phần $\mathrm{TB}$ cho thấy $\mathrm{DVKT}$ phương á kinh tuyến và $\mathrm{TB}-\mathrm{ĐN}$ phát triển mạnh trong các thành tạo có tuổi trước Kainozoi và thể hiện ở rất nhiều nơi (ở khu vực huyện M'Đrắk, Ea Kar, Buôn Đôn của tỉnh Đắk Lắk). Trong khi đó dập vỡ phương vĩ tuyến và á vĩ tuyến lại phát triển mạnh trong đá trầm tích tuổi Meszoi (ở vùng phía nam vùng nghiên cứu), cụ thể là ở khu vực huyện Lắk, Krông Ana, Krông Nô (hình 5). Với vùng phủ basalt (địa phận Tp. Buôn Ma Thuột, huyện CưM'Gar, huyện Krông Búk) thì sự phát triển dập vỡ kiến tạo thể hiện yếu hơn. Trong số dập vỡ kiến tạo các phương tồn tại ở đây thì phương ĐB-TN thể hiện rõ hơn, nhất là ở khu vực tây nam (trên địa phận tỉnh Lâm Đồng) thuộc phần $\mathrm{TB}$ vùng nghiên cứu.

Khác với phần $\mathrm{TB}$, ở phần $\mathrm{ĐN}$ vùng nghiên cứu thì dập vỡ phương ĐB-TN thể hiện nổi trội hơn hẳn và dập vỡ phương TB-ĐN cũng thể hiện khá sắc nét nhưng kém hơn. Dập vỡ kiến tạo phương kinh tuyến và á vĩ tuyến cũng tồn tại ở phần này, nhưng rất thưa thớt. Sự khác biệt nhau về phương phát triển chủ đạo của dập vỡ kiến tạo trong vùng nghiên cứu gợi ý tính dập vỡ ở đây phụ thuộc nhiều vào đặc tính cấu trúc của nền móng hay bị ảnh hưởng mạnh bởi hoạt động của các đới đứt gãy cùng phương (đứt gãy Tuy Hòa - Củ Chi, đứt gãy Nha Trang - Tánh Linh) (hình 12).

Đặc điểm phân bố DVKT ở phần này cũng thể hiện rất phức tạp theo không gian. Nếu như ở nửa ĐB và ở cuối $\mathrm{TN}$ của phần này mật độ $\mathrm{DVKT}$ phương ĐB-TN phát triển dày nổi bật thì các phương khác lại mờ nhạt. Ở các khu vực còn lại thì ngoài DVKT phương ĐB-TN, còn có thêm phương khác (TB-ĐN) phát triển vuông góc lại (như thể là hệ cộng ứng) cũng rất rõ nét (hình 5 và 13). 
L.T. Việt và nnk/Tạp chí Các Khoa học về Trái Đất, Tập 38 (2016)

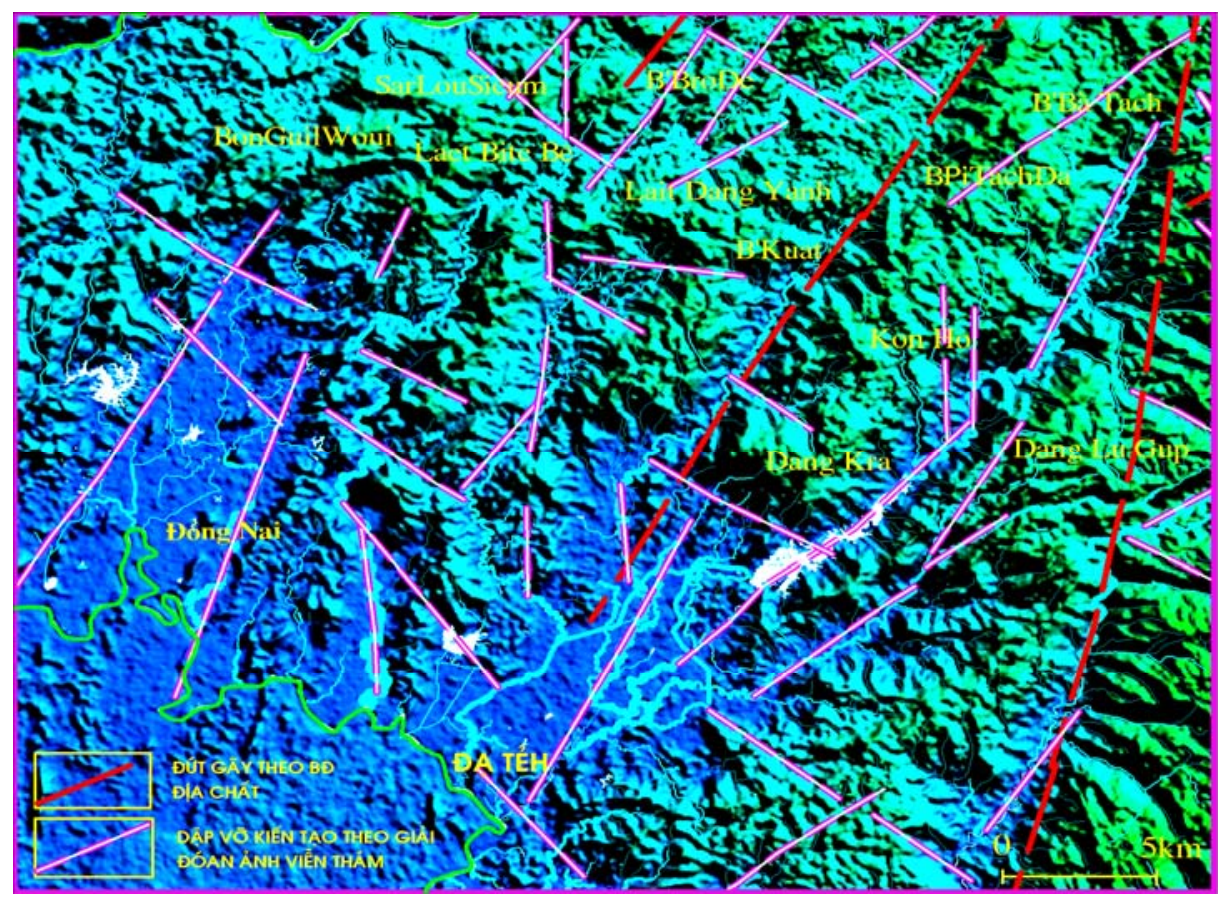

Hình 12. Dập vỡ kiến tạo phương ĐB-TN thể hiện nổi trội ở phần cuối TN của đới đứt gãy Tuy Hòa- Củ Chi

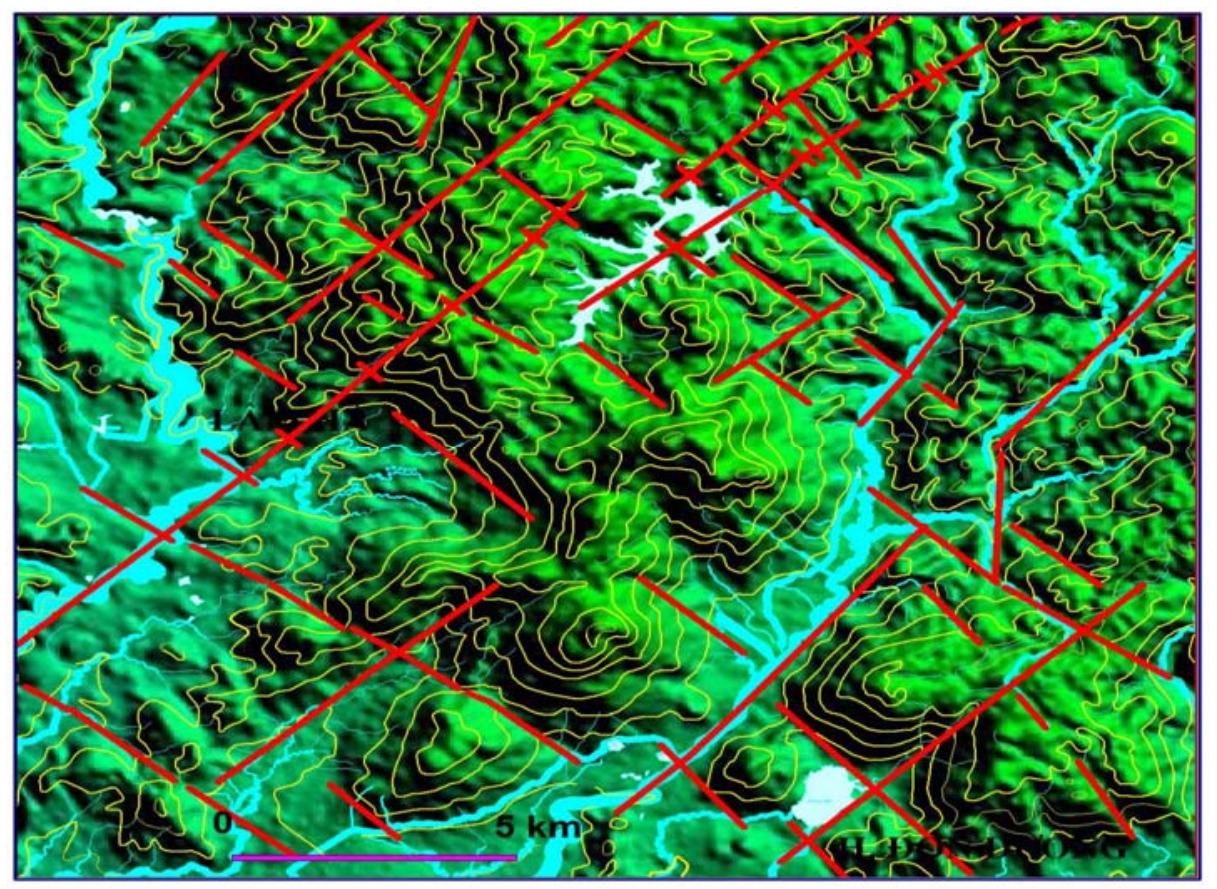

Hình 13. Dập vỡ kiến tạo phương TB-ĐN phát triển gần vuông góc với dập vỡ phương ĐB-TN ở khu vực Lâm Hà - Đức Trọng, Lâm Đồng 
Tạp chí Các Khoa học về Trái Đất, 38 (1), 22-37

Thống kê trên vùng nghiên cứu cho thấy có tới hơn 140 dải dập vỡ (chưa phân chia mức độ tin cậy) có kích thước dài từ $7 \mathrm{~km}$ trở lên (dài nhất khoảng $90 \mathrm{~km}$ ) tồn tại (xem danh sách các dải dập vỡ). Trong số đó số dải có chiều dài dưới $25 \mathrm{~km}$ là chủ đạo. Các dải dập vỡ có chiều dài lớn thường tồn tại ở vùng địa hình phân dị mạnh (các dải thuộc đới đứt gãy Tuy Hòa - Củ Chi, đới đứt gãy Nha Trang- Tánh Linh). Còn ở nơi có lớp phủ basalt thường phát triển các dải dập vỡ có chiều dài hạn chế và đứt đoạn.

Danh sách các dải dập vỡ kiến tạo khu vực Nam Tây Nguyên được liệt kê dưới đây và số hiệu được thể hiện trên sơ đồ hình 5.

3.1.1. Dập võ̃ phuơng Đông Bắc- Tây Nam, gồm các dải

Buôn Tlung (1), sông Ea Krông Hnăng (2), Krông Pắk (3), Buôn Ma Thuột- Krông Năng (4), suối Ea Dâng (5), suối Ea Kuhi (6), suối Da K' Sar (7), Chư Yang Sin (8), suối Dak Liêng (9), suối Ia Hieo (10), suối Dak R'sung (11), sông Dak Rpeul (12), Chư Binh (13), Chư Binh (14), suối Ea Khak (15), suối Ea Krông Tut (16), Chư Tupsa (17), suối Yang Krin (18), Bông Krang (19), suối Dak Ke Gui (20), suối Drco (21), suối Da Lam Bou (22), Dak Heur 2 (23), hồ Dan Ka (24), Da Deun 1 (25), hồ Tùng Lâm (26), hồ Cam Ly (27), Van NinhTánh Linh (28), Đạ Đờn- Đa Sar (29), suối Da Muông (30), suối Da Rcao (31), Đạ Hiông (32), Tà Năng- Lạc Xuân (33), suối Da La Rou (34), Gia Thạnh (35), Phú Hiệp (36), suối Đa Nhim 1 (37), Tà Hine- Phú Hội (38), Quảng Trị- Đam Rông (39), suối Da Nour (40), suối Da Dran (41), suối Da Poti Poul (42), suối Đạ Ploa- Liên Đầm (43), suối Da Moat (44), Hòa Bắc (45), suối $\mathrm{Pa}$ R'sos (46), Gung Ré- Tam Bố (47), Hòa Trung (48), Lộc Châu- ĐaM'ri (49), suối Da Trang (50), Gia ViễnPhước Cát 1 (51), sông Da R' Miss (52), sông Da Nhar (53), buôn Phy Đưng (54), suối Da Prou (55), Quảng Khê (56), suối Da R'Pi (57), suối Dak Nur (58), Nhân Cơ (59), suối Dak Ker 60), suối Dak Noh (61), suối Da Tang Dinh (62), Thuận HạnhĐắk Môl (63), suối Đak Moli (64), suối Dak N'Dro (65), suối Dak Sôr (66), Đắk Mil - Tuy Đức (67), suối Dak Gang (68).

3.1.2. Dập võ phuoong Tây Bắc - Đông Nam, gồm các dải

Hồ Đức Lập (69), Buôn Đierra (70), Jer Bri (71), suối Dak N' Dreh (72), suối Dak N'Drung
(73), Đắk Song- Gia Nghĩa (74), suối Dak Buk Sao (75), suối Dak R'Mo (76), suối Dak Bon Glon (77), suối Ea Puch (78), suối Ea Kuăng (79), sg. Krông Búk (80), Ea Knốp (81), buôn Krông Á- Ea Păn (82), sg. Krông Jing (83), suối Ea H'MLay (84), suối Ea M'Doal (85), suối Ea Krông Hin (86), suối Ea Ral (87), Chư Dian (88), Chư Yang Gri (89), buôn Yang Mao (90), suối Dak Tar (91), suối Da B'Nom Kon (92), Đạ Chay (93), suối Dbuôn M Pouira (94), Rô Men (95), suối Vàng (96), Tà Nung (97), Phú Sơn- Gia Lâm (98), suối Da Ka Nan (99), suối Da Mê (100), suối Bo Kian Bun (101), Nam Ban- Thạch Mỹ (102), Phú HộiTà Nung (103), suối Ka Sô (104), suối Da Lah- Da Queyon (105), Tân Lập- Tà Non (106), suối Da Riam (107), Tân Châu- Tam Bố (108), suối Nhăn (109), suối Da R' Kall (110), Lộc Tân (111), suối Da R' Gna (112),Lộc Lâm- Lộc Bảo (113).

3.1.3. Dập võ̃ phuoong vĩ tuyến và á vĩ tuyến, gồm các dải

Buôn Đôn - Chư Đăng (114), suối Ea Toul (115), suối Ea Nang (116), hồ Phong Gah (117), hồ Bàu Dài (118), suối Ea Kram (119), hồ Đỉa (120), hồ Bầu Xanh (121), hồ Buôn Triết (122), suối Ea Bông (123), suối Dak D'Ro (124), suối Ea Ktour (125), suối Ea Mal (126), Buôn Cung Klang (127), Da Thọ (128), Lộc Đức- Sơn Điện (129), s. Dak Trou (130)

3.1.4. Dập võ phuoong á kinh tuyến và kinh tuyến, gồm các dải

Sông Dak Ken (131), suối Dak N'Bun (132), suối Dak Sirr (133), suối Ea Drik (134), Buôn Trum (135), suối Ea Nioen (136), suối Ea Kung (137), Ea Pal (138), suối Dak Krung (139), sông Dak R' Tih (140), Gia Nghĩa- Da Huoai (141), suối Da Bình (142).

Dập vỡ kiến tạo thường tồn tại trùng với thung lũng các hệ thống sông, suối lớn. Tuy nhiên, cũng quan sát thấy nhiều dải dập vỡ không trùng với thung lũng sông, suối mà xuyên cắt ngang các vai địa hình như các dải dập vỡ: Buôn Ma Thuột K'rông Năng (4), Hòa Bắc (45), Tà Nung (97), Nam Ban - Thạch Mỹ (102), Tân Lập - Ta Non (106),...

Trên địa phận nghiên cứu rất nhiều dải dập vỡ kiến tạo tồn tại trùng với ranh giới địa chất như: 


\section{L.T. Việt và nnk/Tạp chí Các Khoa học về Trái Đất, Tập 38 (2016)}

dải dọc sông Dak Rpeul (12), dải Phú Hiệp (36), suối Da Poti Poul (42), s. Ea Krông Jing (83).

Một số nơi các dải dập vỡ phát triển trùng với các đứt gãy trượt bằng được xác định qua tài liệu địa chất (các dải dập vỡ: sông Dak Rpeul (12), dải Phú Hiệp (36), Tà Hine- Phú Hội (38), Quảng Trị Đam Rông (39), Đắk Mil - Tuy Đức (67), Tân Châu-Tam Bố (108),...

\subsection{Một số đới dập võ̃ quan trọng}

Trong số hơn 140 dải dập vỡ có chiều dài trên $8 \mathrm{~km}$ tồn tại trong khu vực thì có nhiều vị trí mà ở đó nhiều dải ngắn, nhỏ tập hợp tạo thành một đới dập vỡ lớn khá nổi bật. Đó là các đới dập vỡ: M’Đrắk- Cát Tiên (thuộc đới đứt gãy Tuy Hòa- Củ Chi), Khánh Vĩnh - Di Linh (thuộc đới đứt gãy Đèo Cả - Tánh Linh), hồ Đơn Dương - Gia Bắc (thuộc đới đứt gãy Nha Trang - Tánh Linh). Chiều dài phần lớn của các đới này nằm trùng với các đới đứt gãy đã được các công trình nghiên cứu (Phạm Văn Hùng, Nguyễn Trọng Yêm, 1998; Phạm Văn Hùng, 2000; 2002; Nguyễn Xuân Sơn, 1996; Ngô Gia Thắng, 1995; Trần Văn Thắng, Văn Đức Tùng, 2004; Trần Văn Thắng, Văn Đức Tùng, Nguyễn Thị Thanh Hương, 2006; Trần Văn Trị, Vũ Khúc (đồng chủ biên) và nnk, 2009; Cao Đình Triều, Phạm Huy Long, 2002; Lê Triều Việt, 2005; Lê Triều Việt và nnk., 2013; 2015) đề cập.

Đới dập vỡ Tuy Hòa- Củ Chi hay M'Đrắk - Cát Tiên (hình 5 ) với chiều rộng từ vài kilomet đến cả chục $\mathrm{km}$, bao gồm nhiều dải ngắn có phương chung ĐB-TN, như: dải suối Chư Yan Sin (8), sông Dak Rpeul (12), buôn Chu Binh (14), buôn Yang Krin (18), Quảng Trị - Đam Rông (39), Gia Viê̂n - Phước Cát 1 (51), sông Da R' Miss (52), sông Da Nhar (53), buôn Phy Đưng (54), Quảng Khê (56), suối Da R'Pi (57).

Đới này bắt đầu từ phía $\mathrm{B}$ của huyện M'Đrắk) kéo dài về phía TN, qua xã Ea Trang (huyện M'Đrắk), xã Cư Drăm (huyện Krông Bông) đến suối Dak Kao (huyện Lắk) thì tách nhánh. Nhánh chính nằm ở phía bắc, kéo dài từ thượng nguồn sông Dak Mé về hướng TN đến sông Đam Rông thì dừng lại. Nhánh phụ chạy qua xã Đắk Phơi, Buôn Phi Di A (h. Lắk), qua xã Đắk Hà, Đắk Nia (h. Đắk Nông) và kéo dài về phía $\mathrm{TN}$ qua xã Lộc Bắc (h. Bảo Lâm) và huyện Cát Tiên của tỉnh Lâm Đồng. Chiều rộng của đới thay đổi từ vài kilomet ở phía $Đ B$, đến $8-9 \mathrm{~km}$ ở phần giữa (xã Ea Tang, huyện M'Đrắk) và mở rộng đến gần $20 \mathrm{~km}$ như ở phần TN (huyện Đắk G'Long). Với chiều dài trên $200 \mathrm{~km}$, mặt dập vỡ chính ở nhiều vị trí thuộc các dải khác nhau (mặt cắt M'Đrắk, Tách Kar, Krông Nô) nghiêng về phía TB với góc dốc đến $75-85^{\circ}$. Trong giai đoạn Đệ Tứ - Hiện đại đới dập vỡ thể hiện như một đới đứt gãy trượt bằng thuận-tách hiện đại (Phạm Văn Hùng, 2000; 2002). Đây là đới đứt gãy hoạt động lâu dài (từ cuối Mesozoi đến hiện đại) nên tính dập vỡ thay đổi phức tạp trong không gian.

Một đại diện khác của đới dập vỡ kiến tạo phương ĐB-TN là đoạn hồ Đơn Dương - Gia Bắc của đới đứt gãy Nha Trang- Tánh Linh. Đới dập vỡ này có phương chung là $\mathrm{ĐB}-\mathrm{TN}$, rộng đến $6-10 \mathrm{~km}$ trùng với phương kiến trúc của đới kiến tạo Đà Lạt. Với độ dài khoảng $220 \mathrm{~km}$, đới dập vỡ này kéo dài từ Nha Trang, chạy theo phương ĐĐB-TTN, dọc thung lũng Suối Dầu, qua Tô Hạp, đến sườn đông bắc núi Chuẩn. Từ đây đới đứt gãy lệch sang phương ĐB-TN, chạy qua hồ Đơn Dương, Lạc Thạch, Ninh Loan, Đông Giang rồi kéo dài về hướng NTN đến địa danh Sông Phan. Đới dập vỡ gồm các dải ngắn như: hồ Đạ Ròn (32), suối Đa Nhim (37), Thanh Hòa - Ta Non (38). Tại nhiều vị trí khảo sát quan sát thấy mặt trượt của nó đổ về ĐN với góc dốc đến $75-80^{\circ}$. Tài liệu xử lý khe nứt kiến tạo cho phép nhận định: trên phần lớn chiều dài đới dập vỡ thể hiện là đới đứt gãy trượt bằng trong giai đoạn Tân kiến tạo.

Ngoài 2 đới vừa nêu, trên địa bàn nghiên cứu còn một đới dập vỡ khá sắc nét nữa là Khánh Vĩnh - Di Linh (thuộc đới đứt gãy Đèo Cả - Tánh Linh). Đới này có chiều dài cũng gần $200 \mathrm{~km}$ và rộng đến hơn $10 \mathrm{~km}$, bao gồm nhiều dải ngắn, như: hồ Cam Ly (27), sông Đa Nhim (28), suối Da Ka Ban (29), suối Da Tiao (35), Phú Hiệp (36), suối Dak Nur Sebiat (46).

Ngoài các đới dập vỡ và các dải dập vỡ có quy mô lớn phân bố ở vùng địa hình núi phân dị mạnh như vừa đề cập, trên địa bàn Tây Nguyên cũng tồn tại nhiều dập vỡ khác nữa nhưng quy mô không lớn và phần lớn chúng tồn tại trên các địa hình cao nguyên. Tuy nhiên, các đới dập vỡ ngắn này mới là các cấu trúc cần được nghiên cứu chi tiết phục vụ cho việc tìm kiếm nước cũng như bổ cập nước nhân tạo trong tương lai. Vì rằng các cao nguyên 


\section{Tạp chí Các Khoa học về Trái Đất, 38 (1), 22-37}

basalt là nơi dân cư tập trung đông đúc, trồng trọt cũng như chăn nuôi và sản xuất công nghiệp ngày càng phát triển. Do đó nhu cầu rất lớn về nước sẽ gây áp lực lên việc cung cấp nước vào lúc khô hạn.

Bằng việc nghiên cứu đối sánh tổng hợp các dữ liệu của các phương pháp nghiên cứu: Địa hìnhđịa mạo - ảnh viễn thám, địa chất, địa vật lý, địa chất thủy văn chúng tôi đã xác định được một số dải dập vỡ có tiềm năng lớn về nước dưới đất cũng như là các vị trí thích hợp cho việc bổ cập nước nhân tạo vào lòng đất. Đó là các dải: suối Da Rcao (31), Thanh Hòa - Ta Non (38), thôn Hòa Nam (44), hồ Đạ Bò A (51), suối Dak Sôr (66), suối Da Mê (100), Lạc Thạch (101), suối Ea Kram (119), hồ Đỉa (120), hồ Bầu Xanh (121).

\section{Kết luận}

Dập vỡ kiến tạo vùng Nam Tây Nguyên rất đa dạng và phức tạp. Chúng phát triển trên mọi địa hình từ vùng núi cao đến vùng địa hình đồi và thung lũng đồng bằng bóc mòn. Chúng có mặt chủ yếu trong các thành tạo trầm tích, xâm nhập và phun trào có tuổi từ Meszoi đến Đệ Tứ.

Theo sự phân bố dập vỡ kiến tạo vùng nghiên cứu có thể phân thành 2 phần: phần $\mathrm{TB}$ và phần ĐN. Phần TB đặc trưng bởi sự tồn tại các đới dập vỡ theo cả 4 phương: TB-ĐN, ĐB-TN, á vĩ tuyến và á kinh tuyến. Trong số 4 hệ thống trên thì dập vỡ phương ĐB-TN thể hiện nổi trội hơn đôi chút so với các phương còn lại. Trong khi đó, ở phần $\mathrm{ON}$ vùng nghiên cứu thì hệ thống dập vỡ $\mathrm{OB}-\mathrm{TN}$ thể hiện nổi bật, hệ thống TB-ON thể hiện yếu hơn. Còn các hệ thống á kinh tuyến và á vĩ tuyến thể hiện rất mờ nhạt. Thống kê các dải dập vỡ có chiều dài từ $8 \mathrm{~km}$ trở lên thì trong khu vực nghiên cứu tồn tại tới hơn 140 dải dập vỡ. Số dải dập vỡ có chiều dài dưới $25 \mathrm{~km}$ là chủ đạo.

Dựa vào sự giao cắt của các dải dập vỡ cũng như các tiền đề về tồn tại nước ngầm, chúng tôi dự kiến một số nút giao có triển vọng lớn cho việc tìm kiếm nước cũng như để bổ cập nước nhân tạo, phục vụ khai thác lâu dài cho một số điểm dân cư ở Tây Nguyên vào mùa khô hạn. Tuy nhiên, cần có những nghiên cứu tiếp theo để việc dự kiến có độ tin cậy cao.

\section{Lời cảm ơn}

Các tác giả xin chân thành cám ơn Ban chủ nhiệm chương trình Tây Nguyên 3 đã tài trợ kinh phí cho đề tài nghiên cứu cấp Nhà nước với mã số TN3/T24 và kinh phí cho hoàn thiện bài báo này.

\section{Tài liệu dẫn}

Bankwiz Franz K. List et al., 1992: Processing Lineament, the third UN international training cours on remote sensing application to geological sciences. Berlin, Germany.

Cao Đình Triều, Phạm Huy Long, 2002: Kiến tạo đứt gãy lãnh thổ Việt Nam. Nxb. KH\&KT, Hà Nội, 208tr.

Đoàn Văn Cánh, Nguyễn Thị Thanh Thủy, Đào Đình Thuần, Đặng Đức Nhận, Ngô Tuấn Tú, Đặng Đức Long, 2010: Tài nguyên nước vùng Tây Nguyên và giải pháp thu gom nước mưa, nước mặt đưa vào lòng đất bổ sung nhân tạo nước dưới đất. Tc. Địa chất, số 320 (số đặc biệt kỷ niệm 65 năm ngày truyền thống Ngành Địa chất Việt Nam), tr.188-195.

Lê Triều Việt, 2005: Đặc điểm kiến trúc Tân kiến tạo Nam Trung Bộ. Tc. Các Khoa học về Trái Đất, T.27, 4, 312-321.

Lê Triều Việt, Văn Đức Tùng, Nguyễn Thị Thanh Hương, Vũ Cao Chí, Đào Hải Nam, Nguyễn Văn Luân, Bùi Văn Quỳnh, 2016: Đặc điểm dập vỡ kiến tạo vùng Bắc Tây Nguyên. Tc. Địa chất, loạt A, số 356, 3-4, tr.1-13.

Lê Triều Việt, Vũ Văn Chinh, Văn Đức Tùng, Nguyễn Thị Thanh Hương, Vũ Cao Chí, Nguyễn Văn Luân, Bùi Văn Quỳnh, 2013: Một số kết quả ban đầu nghiên cứu dập vỡ kiến tạo khu vực Bắc Tây Nguyên. Kỷ yếu Hội thảo "Quản lý bền vững đất và nước ứng phó với hạn hán, hoang mạc hóa và lũ lụt vùng Tây Nguyên“. Viện HL KHCNVN: 153169, Hà Nội.

Ngô Gia Thắng, 1995: Đặc điểm kiến trúc Kainozoi Việt Nam. Luận án Tiến sỹ. Lưu trữ Thư viện Quốc gia.

Nguyễn Xuân Sơn, 1996: Giải đóan cấu trúc địa chất miền Nam Việt Nam theo tài liệu từ hàng không, tỷ lệ 1:200.000. Luận án Tiến sỹ. Lưu trữ Thư viện Quốc gia, Hà Nội.

Phạm Văn Hùng, 2000: Xác định tính chất động học của đứt gãy bằng phân tích khe nứt kiến tạo ở khu vực Nam Trung Bộ, Tc. Các Khoa học về Trái Đất, T.22, 2, 113-119.

Phạm Văn Hùng, 2002: Đặc điểm đứt gãy Tân kiến tạo khu vực Nam Trung Bộ. Luận án Tiến sỹ, Lưu trữ thư viện Quốc gia, Hà Nội.

Phạm Văn Hùng, Nguyễn Trọng Yêm, 1996: Kết quả nghiên cứu cơ chế hoạt động của các phá hủy đứt gãy kiến tạo vùng cực Nam Trung Bộ trong Kainozoi. Địa chất và Tài nguyên, Tập 1, 87-100, Hà Nội. 


\section{L.T. Việt và nnk/Tạp chí Các Khoa học về Trái Đất, Tập 38 (2016)}

Phạm Văn Hùng, Nguyễn Trọng Yêm, 1998: Xác định vùng ảnh hưởng động lực đứt gãy tân kiến tạo Nam Trung Bộ. Tc. Các Khoa học về Trái Đất, T.20, 2, 140-144.

Stephen B. Mabee, Kenneth C. Hardcastle, Donald U. Wise, 2005: A Method of Collecting and Analyzing Lineaments for Regional-Scale Fractured-Bedrock Aquifer Studies. Ground Water, Volume 32, Issue 6, pages 884-894.

Trần Văn Thắng, Văn Đức Tùng, 2004: Các đới đứt gãy chính có biểu hiện hoạt động trong Kainozoi muộn trên đới kiến tạo Đà Lạt. Tc. Các Khoa học về Trái Đất, T.26, 4, 554-563.
Trần Văn Thắng, Văn Đức Tùng, Nguyễn Thị Thanh Hương, 2006: Đặc điểm phát triển kiến tạo đới Đà Lạt và kế cận trong Mesozoi muộn - Kainozoi. Tc. Các Khoa học về Trái Đất, T.28, 2, 140-149.

Trần Văn Trị, Vũ Khúc (đồng chủ biên), 2009: Địa chất và Tài nguyên Việt Nam. Nxb. KHTN\&CN, 590tr, Hà Nội.

Bản đồ địa chất và khoáng sản, tỷ lệ 1:200.000 gồm các tờ: Bản Đôn, Bến Khế, Buôn Ma Thuật, Buprang, B'lao, Đà LạtCam Ranh, Giá Ray, Phan Thiết (Tổng Cục Địa chất và Khoáng sản).

Cẩm nang công nghệ địa chất, 2010: Phần IX, công nghệ viễn thám. Nxb. KHTN\& CN, 642tr, Hà Nội. 